\title{
A community of fear: emotion and the hydro-social cycle in East Porterville, California
}

\author{
Michael Egge ${ }^{1}$ \\ Idowu Ajibade \\ Portland State University, USA
}

\begin{abstract}
Broader governance challenges driving water insecurity globally are well documented in the literature, however the power-laden relationships and emotions that shape water access at the household and community levels are yet to be fully investigated, especially in the context of water consolidation projects. In this article, we examine the role of emotions in mediating access to water and in the production of resource struggles among marginalized communities, existing outside of conventional regulatory frameworks. We bring together two relational approaches - the hydro-social cycle and emotional political ecology - to examine water insecurity and how it manifests in the historically disadvantaged Latinx community of East Porterville, California; an unincorporated community faced with seven years of prolonged drought and widespread dry wells. Findings from qualitative analysis of semi-structured interviews with residents and local experts and participant observation revealed that the emotions of fear, suffering, embarrassment, shame, and compassion facilitated the reproduction of water insecurity in certain households while engendering access in others. Social hierarchy and horizontal relationships mattered, particularly in how emotions were mobilized and contested and the effects they produced for households. Furthermore, this article shows that water struggles and solutions are emotional processes with political and livelihood implications and thus require attention beyond engineering solutions.
\end{abstract}

Key words: Water security, emotional political ecology, hydro-social cycle, California, resource access

\section{Résumé}

Les défis de la gouvernance mondiale à l'origine de l'insécurité de l'eau sont bien documentés, mais les relations ou le pouvoir, et les émotions, qui façonnent l'accès à l'eau au niveau des ménages et de la communauté, n'ont pas encore été pleinement étudiés. Cela est vrai pour les «projets de consolidation de l'eau." Dans cet article, nous examinons le rôle des émotions dans la médiation de l'accès à l'eau et dans les luttes de ressources parmi les communautés marginalisées qui existent en dehors des cadres réglementaires conventionnels. Nous rassemblons deux approches relationnelles - le cycle hydro-social et l'écologie politique émotionnelle - pour examiner l'insécurité de l'eau et comment elle se manifeste dans la communauté latino-américaine historiquement défavorisée d'East Porterville, en Californie. Il s'agit d'une communauté non constituée en société confrontée à sept ans de sécheresse prolongée et de nombreux puits secs. Nous avons mené des entretiens semi-structurés avec des résidents et des experts locaux, et une observation des participants. Nous avons constaté que les émotions de peur, de souffrance, de gêne, de honte et de compassion facilitaient la reproduction de l'insécurité hydrique dans certains ménages tout en créant un meilleur accès dans d'autres. La hiérarchie sociale et les relations horizontales étaient importantes, en particulier pour guider la manière dont les émotions étaient mobilisées et contestées, et les effets qu'elles produisaient pour les ménages. En outre, cet

\footnotetext{
${ }^{1}$ Michael Egge, PhD student, and Dr. Idowu Ajibade, Assistant Professor, Department of Geography, Portland State University, Portland, USA. Emails: megge "at" pdx.edu, iajibade "at" pdx.edu. This research was made possible in part by financial assistance from Portland State University and the Ruth Landes Memorial Research Fund, a program of The Reed Foundation. We are grateful to the two anonymous reviewers who provided comments on early drafts. All errors remain our own.
} 
article montre que les «luttes pour l'eau» et les solutions sont des processus émotionnels, qui ont des implications politiques et sur les moyens de subsistance. Ils nécessitent une attention au-delà des solutions d'ingénierie.

Mots clés: sécurité de l'eau, écologie politique émotionnelle, cycle hydro-social, Californie, accès aux ressources

\section{Resumen}

Los grandes retos de gobernanza generados por la inseguridad hídrica a nivel global, están bien documentados en la literatura. Sin embargo, las relaciones de poder y las emociones que configuran el acceso al agua al nivel del hogar y la comunidad, aún deben ser investigadas a profundidad, especialmente en el contexto de los proyectos de saneamiento de agua. En este artículo examinamos el papel que juegan las emociones en la mediación para acceder al agua, así como su papel en la lucha en la gestión de recursos por parte de comunidades marginadas que se encuentran fuera de los marcos regulatorios convencionales. Aquí reunimos dos acercamientos relacionales -el ciclo hidrosocial y la ecología política emocional- para examinar la inseguridad hídrica y cómo se manifiesta en la históricamente desfavorecida comunidad latinx de East Porterville, California: una comunidad desincorporada que enfrentó durante siete años una prolongada sequía y un gran número de sus pozos secos. Hallazgos arrojados por el análisis cualitativo de entrevistas semiestructuradas con residentes y expertos locales, así de como observación participante, revelaron que las emociones como el miedo, sufrimiento, vergüenza, lástima y compasión, facilitaron la reproducción de la inseguridad en temas de agua en ciertos hogares, mientras que generaron el acceso para otros. La jerarquía social y las relaciones horizontales resultaron importantes, particularmente en cómo las emociones fueron movilizadas y cuestionadas, y los efectos que se produjeron para los hogares. Además, este artículo muestra que las pugnas por el agua, así como las soluciones, son procesos emocionales con implicaciones en lo político y en la subsistencia que por tanto, requieren atenciones más allá de las soluciones técnicas.

Palabras clave: inseguridad hídrica, ecología política emocional, ciclo hidrosocial, California, acceso a recursos.

\section{Introduction}

Water is life. Agua es vida. T'a lhdihk xo'en. (Billboard on California Highway 198)

Water is an essential resource for food production, sanitation, and ecosystem health, and with positive impacts on human wellbeing. It is also a resource that has come under threat on multiple fronts, including from population pressure, climate change, exploitative development patterns, pollution, and overuse (Bakker 2012b). These threats underpin on-going water crises in many parts of the world. In the United States, scholars have shed light on these problems in the disadvantaged communities of Flint, Michigan (Pauli 2019; Pulido 2016), in California's Central Valley (London et al. 2018; Ranganathan and Balazs 2015), and along the U.S.Mexico Border (Jepson and Brown 2014). What is often missing in the debate is the differential effects of water crises within and between households. Studies performed at the household scale show how individuals face unique barriers and pathways to water access due to structural inequality and based on their identity, their race, gender, ethnicity, class, and other factors. These challenges create avenues to (re)produce and contest power relations in society (Cleaver and Hamada 2010; Crow and Sultana 2002; Goldin 2010; Harris 2006; Hawkins and Seager 2010; Nightingale 2011b; Sultana 2009; Sultana 2011; Radonic 2019; Truelove 2011, 2019; Wutich 2009, 2011). This article expands on these insights by examining the roles of emotions in mediating household water access among marginalized community members.

We draw on emotional political ecology (EPE), which has recently emerged from the feminist political ecology (FPE) literature, to critically examine the role of emotions and the embodiment of resource struggles (González-Hidalgo and Zografos 2019; Nightingale 2011a; Singh 2013; Sultana 2011, 2015). EPE scholarship suggests that emotion is an actor within, and a product of, resource struggles. Emotions are produced through power relations, social constructions of meaning, and struggles over material resources (Bondi 2005; Davidson and Milligan 2004; Pile 2010; Sharp 2009). Human and non-human actors interact to affect individual 
emotional experiences (Davidson and Milligan 2004). Emotions are also active, playing roles in collective thought, group relations, and access to resources (González-Hidalgo and Zografos 2017; Moore 2005; Schoenberger and Beban 2018; Sultana 2011; Wright 2012).

In this article, we explore how emotions improve and/or worsen water access among various stakeholders. We examine the connections between emotions and water within a broader hydro-social cycle framework. The hydro-social cycle is a theoretical framework that reframes water as a hybrid of society and nature, encompassing its physical, social, and technical aspects. The approach emphasizes how the distribution of water is contingent on historic and contemporary power relations, culture, and relationships as much as its "natural" distribution through the hydrologic cycle (Bakker 2002, 2012a; Jepson et al. 2017; Linton and Budds 2014; Swyngedouw 2009). We draw on these insights to elucidate the structural restrictions on household water access, how this affects emotions, and how the reciprocal emotional impacts affect power relations and the distribution of water in society.

Our case study focuses on a recent water crisis and water system consolidation project in East Porterville, California, a predominantly Latin $x^{2}$ community facing historic and contemporary marginalization. Specifically, we demonstrate the roles of emotion within hydro-social relationships, as both proximate barriers to water access and agents of hydro-social change. We ask: How do social norms and socio-political structures mediate the relationship between water and human emotions? What role do emotions play in the reproduction of unequal water access and distribution? To accomplish this, we draw on participant observation and interviews with residents, local experts, and government officials. The emotions we describe arise from the respondents' use and loss of water, their representation and engagement in civic life broadly, and interactions with other individuals connected to the community.

We first draw on the hydro-social cycle and EPE to understand household water access. In the third section, we introduce the study context to provide an overview of the water crisis and the water project in East Porterville. After describing our methodology and positionality, we offer key findings, focusing on emotional experiences, barriers, and appeals involved in hydro-social relationships in the area, affecting both power and water. Finally, we conclude with recommendations for overcoming emotional barriers to water access.

\section{Hydro-social cycle, emotional political ecology, and water access}

As water comes to embody and express social relations, so it becomes crucial to the production and reproduction of power in the world. (Loftus 2009: 954)

\section{Household water access and the hydro-social cycle}

Conventional approaches to water security tend to focus on quantifying water problems, mainly focusing on the source (e.g. a well), quantity (e.g. liters/day), quality (e.g. concentration of lead), and affordability (e.g. percent of income spent per month) of the water available to households (Wutich et al. 2017). While useful for identifying trends and issues, these measurements lack the critical edge for understanding the structural production and causes of inequity in water access and distribution. In contrast, the hydro-social approach provides a relational framework for exploring the root causes of a problem by focusing on the multiple intersecting factors that shape water insecurity at different scales including at the household level (Jepson et al. 2017). The hydro-social cycle reframes water as a hybrid of society and nature, emphasizing how the contemporary distribution of water is contingent on power relations, technology, and the physical properties of water and the landscape (Bakker 2002, 2012a; Jepson et al. 2017; Linton and Budds 2014; Swyngedouw 2009). Critically, the hydro-social cycle emphasizes the ongoing, cyclical nature of (re)producing water and society simultaneously (Octavianti and Charles 2019; Swyngedouw 2009). In doing so, it challenges the apolitical hydrological cycle, by recognizing the role of humans in determining the flow and composition of water, as well as the power of water to affect social systems (Linton and Budds 2014).

\footnotetext{
${ }^{2}$ Although an imperfect term, we use Latinx instead of the traditional Latino(s) to be gender inclusive in our language (for
} a full discussion, see de Onís, 2017) 
Within this framework, the distribution of water cannot be analyzed separately from historic and current political-economic and socio-cultural circumstances (Cousins and Newell 2015; Hohenthal, Räsänen and Minoia 2018; Perramond 2016). Through time, water security has been heavily influenced by the wealthy and powerful, exemplifying the privilege they hold. For example, elites in Spain mobilized their power and knowledge to alter the waterscape in the name of social and natural reform, cementing them in positions of power (Swyngedouw 1999). Such power relations exert partial control over water, diverting flows and redistributing water across 'unnatural' spaces. However, humans do not hold absolute power over the distribution of water; water maintains an untamable agency, eroding structures, shifting supply, and flow of water is variable over time (Bakker 2012a; Linton and Budds 2014).

Although the hydro-social cycle considers the relationship between embodied cultures and water (Boelens 2014; Linton and Budds 2014; Swyngedouw 2009), emphasis on the former has generally been lacking except in a few studies (see Acharya 2015; Boelens 2014). Across different societies, water is embodied in a culturally significant way, such as in religious activity; as a symbol of life, death, and regeneration; and in individual and collective identity formation (Strang 2005). Furthermore, cultural norms structure who uses water for what purposes, as well as the entity expected to provide the water for the home, whether human, meteorological, governmental, or metaphysical (Boelens 2014). Water takes on significance based not only on one's social positioning, but also through daily, personal experiences using and interacting with it (Walsh 2018). Due to the symbolism, meaning, and norms surrounding water, struggles over it are not simply material or political, but also intellectual, spiritual, cultural, and emotional (Boelens 2014; Dallman et al. 2013; O'Reilly 2006; Orlove and Caton, 2010; Wilson 2014). Investigations into the relationship between cultures and water deserve more emphasis within applications of the hydro-social cycle. A major challenge, however, is that the hydro-social approach lends itself to macro-level analysis, as with irrigation or urban water systems, often giving little attention to the intimate and most common spaces where water is used - in the home for drinking, bathing, gardening, and so on (Walsh 2018). It is in these engagements with water where emotional attachments are formed and norms surrounding water may be contested (Dallman et al. 2013; Sultana 2011; Wilson 2014). Alone, the hydro-social cycle is insufficient for explaining the emotional, embodied experiences and cultures that shape water at the household level. To address this gap, we draw on Emotional Political Ecology.

\section{Emotional Political Ecology}

Emotion is partially formed by social networks and by individual perception; in other words, it is relational in nature (Bondi 2005; Pile 2010). Emotions are simultaneously intrapersonal, occurring within the self as an internalized feeling, as well as interpersonal, produced through interactions within the social and natural environment (Main et al. 2017). Put another way, individual reactions are filtered through cultural and social constructions which inform how people should perceive events, and interpret and express their feelings and emotions to others (Bondi 2005; Coe and Schnabel 2011; Ford and Mauss 2015; Hochschild 2003). Each of these aspects are dependent on the broader cultural milieu, as well as on the specific situation the person finds themselves in (Coe and Schnabel 2011). Ahmed (2004) asserts that emotion is mobile, circulating between individuals, objects, collectives, and structures. At various points and durations, emotion sticks and elicits response in others: it is never static and always changing. In this sense, emotions may be actors themselves, affecting the self and others in unforeseeable ways, or individuals may actively choose to use their own emotions or to create emotional responses in others. For instance, holders of power mobilize emotional attachments to enhance their position and limit power held by others, thus structuring relationships between themselves and their subjects. In this sense, emotion is neither essentially positive or negative: it acts according to positionality and ability (Ahmed 2004; Munt 2007). Individuals come to identify themselves based on emotional relationships where they can come together as a part of a whole, become restricted and isolated, or otherwise reposition themselves in ways that (re)produce their place in society (Ahmed 2004). Emotion is critical to interpreting the world and forming the self. As such, thinking and decision-making are simultaneously emotional and rational, rather than distinctly one or the other (Bondi 2005; Davidson and Milligan 2004). Furthermore, because emotions are formed as part of social assemblages, they are not just representative of the self, but also of society, culture, and politics (Ford 2020). 
Emotional political ecology draws on the insights and practices of feminist political ecology to explore the intimate spaces of the mind, body, and household as sites for the (re)production of broader power relations, materially and ideologically (Doshi 2017; Elmhirst 2011; González-Hidalgo and Zografos 2019; HayesConroy and Hayes-Conroy 2010, 2013; Nightingale 2011a; Singh 2013; Sultana 2009, 2011, 2015). EPE scholars have shown that individuals negotiate resource access daily and across generations through cultural and normative performances based on emotion (Moore 2005; Nightingale 2011a; Sultana 2011, 2015; Truelove 2011). In these cases, emotion is reactive, formed in individuals within the context of cultural norms and interactions, and pro-active, capable of affecting individual and community level access (Jewitt and Ryley 2014; Sultana 2011). On the one hand, emotion can form a barrier to resource access. Politically, the state can engage in forms of biopower to induce emotions like fear through discourse, which can prevent action during resource conflicts (Schoenberger and Beban 2018). Culturally, differences in social status can create discomfort and feelings of inferiority in stakeholders, reducing engagement in otherwise participatory governance (Goldin 2010; Morales and Harris 2014; Nightingale 2013). On the other hand, emotions may also produce conditions necessary to secure resources (González-Hidalgo and Zografos 2017; Wright 2012). González-Hidalgo and Zografos (2017) demonstrate how collective anger and grief can create emotional unity, inspiring social movements in the face of state power. Drawing on these insights, it is apparent that emotions can have various, often conflicting, effects on resource struggles. Some scholars have put forward affective political ecology as a similar but distinct approach (Singh 2018). While a worthy endeavor, we focus on EPE scholarship that prioritize personal accounts of feelings and emotion, rather than 'affect', a term that discounts subjective experience in favor of bodily responses unfiltered by cognition (Bondi 2005; Pile 2010; Sharp 2009).

Emotional political ecology and the hydro-social cycle fit together as complementary relational approaches to elucidate the dynamics of household water insecurity in our case study. Complex hydro-social structures may provide the basis for contemporary distribution and values surrounding water, but there is much diversity in daily, bodily interactions with and without water (Walsh 2018). It is in these spaces, we argue, that individuals form emotions that limit and/or enhance their own water access, and potentially network with other human and non-human actors to affect hydro-social structures themselves. We draw on these ideas to analyze a case study in East Porterville, California.

\section{Water struggles and water solutions in East Porterville}

Before describing the contemporary conditions in East Porterville, we will briefly discuss historic exploitation of labor and water in California. Since the 1800s, white Californians have exploited racialized labor groups (Ngai 2014) and water (Reisner 1993) in the name of capital development. Gold, canals, railroads, and farms defined the first century of California's growth. During this time, white entrepreneurs systematically oppressed immigrant, Black, and Native laborers (Ngai 2014). Various immigrant groups - including Chinese, Japanese, and Mexican populations - were brought to the state to work, but were often prevented from attaining citizenship, land, or rights, and by extension water rights (London et al. 2018; Ngai 2014). After an immigrant group grew substantially, they were often deported or excluded from future immigration plans. As these groups were exploited, urban and agricultural powerbrokers seized control of the waterways through legal means, water rights, and a system of dams and canals. All the while, groundwater use went unregulated until 2014, leading to severe overdraft and irreparable damage to numerous sub-basins of the Central Valley Aquifer (Faunt et al. 2016; Lund et al. 2018). Groundwater depletion disproportionately harms domestic water accessibility, especially in rural communities, because those wells are often shallower than those for agriculture (Perrone and Jasechko 2017).

Over time, corporate and state control of water has led to significant capital gains at the expense of the human and ecological communities they serve (Reisner 1993; Walker 2004; Worster 1982). Today, discourse surrounding 'illegal' immigration continues to portray Latinx immigrants as unworthy of residence in America (Ngai 2014), water continues to flow based on water rights established decades ago (Sugg 2018), and domestic wells often run dry (Perrone and Jasechko 2017). Given the historic inequities in land tenure and water rights, immigrants' families and their descendants disproportionately lack control over water and often live in historically disadvantaged communities that are water insecure (London et al. 2018; Worster 1982). 
East Porterville is one of several drought-prone communities in California faced with the fear and reality of water insecurity. It is an unincorporated community that lies on the outskirts of the City of Porterville in the Southern Central Valley of California (see Figure 1). Incorporated areas, or cities, are defined by their local governing authority - cities have defined boundaries in which they provide services to residents in return for taxes. Unincorporated towns are defined by their proximity to cities but lack the same quality of area services - they lack local governance and pay taxes to a county which provides (fewer) services over a larger area (Cohen, Hatchard and Wilson 2015). East Porterville occupies a peri-urban space, a unique geographic position between the urban-rural divide, and a transition zone of sorts (Anderson 2007). Peri-urban unincorporated areas often house marginalized populations who are unable to live in, or have been excluded from, the city proper (Anderson 2007).

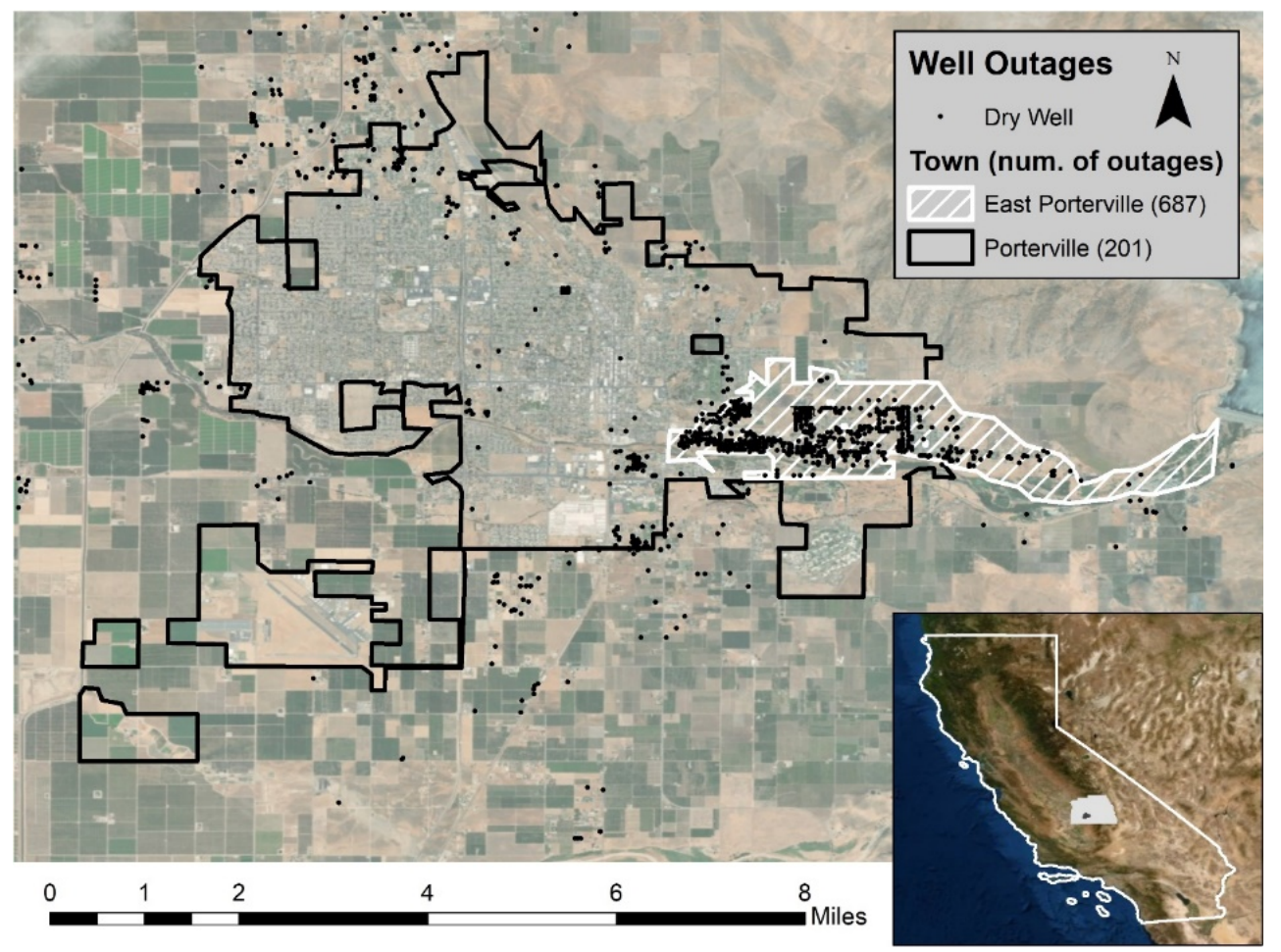

Figure 1: Map of well outages due to water shortage or contamination in Porterville (201), East Porterville (687), and the surrounding area. Data: Tulare County Office of Emergency Services, Esri, DigitalGlobe, GeoEye, Earthstar Geographics, CNES/Airbus DS, USDA, USGS, AeroGRID, IGN, and the GIS User Community.

East Porterville consists of an estimated seven thousand residents that are made up of predominantly low wage, Hispanic/Latinx families (London et al. 2018). Many of these residents are either presumed to be undocumented, temporary migrant laborers, or are attempting to gain legal citizenship. Being unincorporated, East Porterville is under Tulare County jurisdiction, making it politically disconnected from the City of Porterville, although physically linked by roads and sewer lines. During the 2011-2017 California drought, East Porterville experienced hundreds of well outages due to water shortage and contamination. Well outages became distressingly common throughout California during the drought, but East Porterville had the highest reported concentration (Fears 2016). East Porterville residents relied solely on private household wells for their 
water supply prior to and during the drought, whereas the City of Porterville had access to deeper, publicly managed wells that fed a city-wide water system. In many ways, East Porterville only represents one example of water struggles and environmental injustice in California (see Balazs et al. 2011, 2012; Cantor 2017; Dallman et al. 2013; London et al. 2018 and Ranganathan and Balazs 2015).

During the drought years, residents had multiple avenues for obtaining temporary water supplies. Community members organized bottled water drives, and shared with one another for free; individuals connected their personal wells to their neighbor's home through hoses; and some drilled new wells on their properties. Government agencies and non-profit groups also organized water drives and distributed water bottles at centralized locations. The county set up a large tank at the local fire station where residents could fill barrels with water to bring home. Eventually, non-profits began to connect 300-gallon (1,136 liter) water tanks to homes to provide a temporary, albeit undrinkable, water supply. Later, the state began to connect 2,500gallon (9,464 liter) tanks, refilling them periodically with water trucks. Ultimately, it implemented a water system consolidation project, connecting the City of Porterville water system to East Porterville households free of cost (London et al. 2018).

It is important to note how residents were able to access the water sources listed above. Informal water was gained through interpersonal relationships and communication, whereas formal water sources required residents to report their water shortage to organizations, including the government. To connect to the city water supply through the water consolidation project, residents had to fill out paperwork concerning their property ownership and proof of residency. Renters relied on landlords to go through this process. Households could connect to the city water supply regardless of whether they experienced a well outage during the drought. Not all residents took advantage of the project - about 345 of 1,100 eligible homes did not sign up (Department of Water Resources 2018).

\section{Methods}

This study was conducted using two qualitative methods: participant observation and semi-structured interviews. The first author performed participant observation at a local non-profit organization to immerse himself in the community, make connections, and to inform later interviews (Creswell and Miller 2000; Emerson et al. 2011). Semi-structured interviews helped to elicit perspectives and responses on the drought, and to expand on our initial findings (DiCicco-Bloom and Crabtree 2006). Fieldwork in East Porterville was conducted between July through August 2018 and January through February 2020, and 37 stakeholders were interviewed. Recruitment was performed through snowball sampling, leading to interviews with 21 residents, 11 local experts, and 5 government officials. Demographically, 24 participants identified as Latinx, 12 as white, and one as "Texican." In terms of gender, 15 identified as women, 20 as men, and 2 as genderqueer. Two interviewees mentioned that members of their family came to California without immigration documents. All names used are pseudonyms, apart from government officials who declined anonymity. Many interviews were done in a mixture of English and Spanish with the aid of an interpreter.

Analysis followed an inductive approach, gathering data reflexively, revising and updating the research and interview questions accordingly (Thomas 2006). Six emotional themes emerged from the analysis: fear, embarrassment, shaming, suffering, compassion, and sympathy. We coded these emotional themes based on either the direct language provided by respondents (fear, embarrassment, shaming) or an overarching experience (suffering, compassion, sympathy). Themes using the direct language provided by respondents identify emotions they either felt (fear and embarrassment) or tried to make others experience (shaming). Overarching emotional themes describe a range of feelings that can fit under one succinct term. For example, suffering was coded according to feelings of sadness, trauma, and the difficulty associated with living without water in the home.

We would also like to address the positionality of the researchers in this study. The first author and field researcher is a white American citizen from an upper-middle class family. The second author, who served an advisory role interpreting the data and writing our findings, is Black and an African immigrant to the U.S. These identities are quite different from the residents of East Porterville who face unique stigma for their actual and/or perceived (undocumented) immigration status (Lawson, Jarosz and Bonds 2010). The field researcher 
was in a position of security and power within the community, unaffected by the threat of police profiling and immigration enforcement, with a secure income and source of water. Being white and living outside of the community made his outsider status evident to community members and likely limited some individuals' participation in the project. This difficulty mirrored sentiments by officials and community leaders who either witnessed or experienced similar problems. To the best of our ability, we moderated these effects by entering the community through trusted gatekeepers, involving residents in translation, and using verbal consent to interviews, ensuring anonymity. Local experts acted as crucial resources to represent the undocumented community's experience, without having to expose anyone's documentation status. Considering the relational aspect of emotion research (Bondi 2005; Sharp 2009), our positions as outsiders to the community and legal residents in the country limits our ability to fully embody participants' struggles, because no matter how much we read of their experiences or speak to them, we cannot know, in a bodily sense, how they felt during these times (Bondi 2007). Following Rose (1997), we recognize that this research is a partial understanding of reality, produced in concert between the researchers and participants. In the following sections, we discuss the findings of our study, showing the relationships between (a lack of) water, emotions, individuals, communities, and structures that (re)produce unequal distributions of power and water.

\section{Water access and suffering}

During and after the period of well outages, our study reveals that the majority of respondents were emotionally affected by the material lack of water. Many of them described the feelings of sadness and suffering over the loss of water. While these feelings did not prevent them from accessing some water, they provide important cues for understanding the emotional effects of water loss in the community.

\section{Suffering during the drought}

Dry wells in the community led to the loss of water, inability to perform daily tasks, and a change in the landscape, thus producing feelings of sadness and suffering across the community. Reflecting on their experiences before the drought, many residents described the pride they had in having water and in gardening. Ramona, a young Latina woman, described the comfort she felt when listening to the well operate, and how its absence leaves an emptiness behind. Similarly, her father held pride in his well water, especially after it passed a quality test. But when the drought hit, he resorted to extreme measures, trying to regain access:

He was proud of his water, so when [the drought] happened, he felt down. He digged, and then, for a point, we got water, but then it dried up again... I remember he was digging, and my dad, sometimes it's hard, he's sick and everything, so it was tough for him to do stuff. But he was digging somehow. (Ramona, Latina, East Porterville Resident, 16 Aug. 2018)

Ramona's father was emotionally desperate for water-he felt like he could not provide for his family, and that he had lost something valuable. In this case, value stems as much from the pride in water as it does from its economic or consumptive uses. This loss affected him physically and psychologically. Despite his age and sickness, he tried to deepen the well by hand to provide water for his family. Materially, the lack of water created emotional experiences, which in turn drove physical attempts to regain access. In this way, we see a connection between physical trauma, emotional distress, and the loss of water.

\section{Lasting trauma}

Even after the water shortage ended, emotional experiences persist; not all the residents' pain and suffering were resolved by the water project. One respondent, a Latina woman (Latina, East Porterville Resident, 8/11/18), lost her house when it burned down during the drought because there was no fire service in East Porterville. A fire truck arrived from a county fire station but ran out of water before the fire was extinguished. She described this period of her life - through a water shortage and fire - as a "trauma." Her loss 
was emotionally visceral and could not be remedied through the consolidation project that supplied mains water after she lost her home.

Other residents reported their sadness and a sense of loss over their gardens. In the community, gardens, orchards, and trees represent more than a food source or a decoration: they provide a cornerstone for culture, pride, and family. For example, many of the rose bushes in the area were gifts from daughters to mothers. Without water, these plants withered, and many died, leaving behind a deep sense of loss:

When the garden dried up, I felt really bad because apart from all my plants, I couldn't do my things, the necessities in the house, washing, I would go out and see that everything had dried up. Everything was completely dry and had no life, there was nothing, and I truly felt really sad. (Isabel, Latina, East Porterville Resident, 8/9/18, translated from Spanish)

If the struggle of not having water for chores was not enough, the pain of losing her garden brought Isabel deep sadness. The garden provided life, food, and beauty to their yard. It was also a place her late husband helped plant and tend. Such effects are irreparable—a new garden can be planted, but it will not be the same as the one raised by their family member.

Notably, the inability to use water for household chores created distress and suffering, primarily among women who were expected to perform these duties. This gendered relationship with water has an intimate, embodied effect on individuals experiencing water shortage. For men like Ramona's father, they felt distressed over the inability to provide water, a crucial resource, for their families. They often took this as a personal failure and significant blow to their pride.

In line with the findings of Sultana (2011) and Moore (2005), residents came to embody the water shortage in East Porterville in ways that reflected their marginalization, lack of power, and their gender roles in society writ large. A lack of political representation, associated with the unincorporated status of the town and the often-undocumented status of residents, is reflected in the lack of water across the community. This is also associated with a cultural process of failing to invest in racialized rural Latinx communities in the U.S. because they are perceived as unworthy (Lawson, Jarosz and Bonds 2010). East Porterville has been a neglected community for decades that had already created a fertile ground for struggle; the recent water shortage and suffering are only additional burdens for the residents on top of these factors. Suffering continues to persist among local residents, extending the timeline and salience of the water shortage as residents grieve over what cannot be regained. Outside of East Porterville, there were similar effects of the drought, but they were often mitigated by relative wealth, access to city resources, and positions of privilege.

\section{Emotional barriers to water access}

Goldin (2010) argues that shame and mistrust prevent broader participation in water governance. Working in South Africa, she shows how the historic and present subjugation of people sustains a mistrust of the post-apartheid government, leading to feelings of shame and fear which prevent engagement with public forums. Alongside other factors, this is one of the main reasons that inequities persist. In East Porterville too, the lack of water among households interacted with cultural and political struggles, producing fear and embarrassment, which in turn affected water access.

\section{Fear and politics}

One local expert described "a spirit of fear" in East Porterville where residents avoided government contact for fear of deportation from the country and separation from their children. Outside of the context of water, there was a constant mistrust of the government and outsiders. This fear is entangled in the history of marginalization of Latinx immigrants in California and the U.S. more broadly. California has developed the modern rhetoric around 'illegal' immigration where multiple groups have been systematically disenfranchised (Ngai 2014; Street 2004). The consistently apprehension and high deportation rates of Latinx individuals and families affects their political engagement (Street, Zepeda-Millán and Jones-Correa 2015) and their ability to 
access public resources in times of need (Collins 2010). For example, immigration status is a crucial factor in determining water security on the Texas-Mexico borderlands (Jepson and Vandewalle 2016). East Porterville has a large Latinx migrant population, many of whom are presumed to be undocumented or attempting to gain citizenship. This puts them in a precarious position daily. Immigrants, authorized or not, mistrust the local and state government's motives. As Zhen et al. (2020) demonstrate, trust may be a limiting factor for water management depending on the level of risk and reliance on the government. When the drought worsened, the people of East Porterville could only turn to the government for long-term help, making trust a crucial factor for regaining water access.

In East Porterville, mistrust led to a salient fear of government interaction during the drought. This fear prevented individuals from approaching local non-profits and government officials when they ran out of water. Throughout the drought period, but especially in the early stages of the water shortage, underreporting hid the scale of crisis and prevented people from getting the help they needed:

So what was documented [of the shortage], and then what the reality of the drought was for the residents was [worse]... And a lot of that has to do with the fear of people coming forward. Not knowing their rights. Not knowing... the help that was there, regardless of their eligibility to be in this country. (Inigo, Latino, East Porterville Resident, 31 July 2018)

Inigo's quote is one of many that exemplify the feelings of fear in the community. While the water situation produces suffering among most community members, Latinx and especially undocumented residents feel the most fear.

Kyle, an environmental justice advocate, described various fears associated with documentation and the unknowable effects of interacting with the government:

Especially when you're dealing with communities that have family members that maybe have a questionable immigration status, [they might lack] documentation on their property, on their immigration status, on the benefits that they're receiving, [then] there's a lot of hesitancy to draw attention to that situation. A lot of mistrust, like 'right now, we're here and we're living a good life and we're flying under the radar and we don't want to upset the apple cart.' (Kyle, White, Environmental Justice Advocate, 8/14/18)

These households would rather rely on themselves or their trusted confidantes to supply temporary water sources, reducing the risk posed by outsiders and officials. To include the government in their lives would create an unknown situation, where their immigration status may be questioned, and they could be deported which may lead to more significant suffering than living without water.

Fear of the government extended beyond the threat of deportation:

There was a child welfare case that the county had been involved in and the children ended up being removed, so the rumor in the community was: the kids were removed because they don't have water. So, don't tell the county you don't have water, because they're gonna take your kids, which wasn't the case. (Denise England, White, County Water Resources Director, 8/20/18)

As Denise's quote shows, government action in the community is given a spotlight, creating rumors and spreading fear. Denise speculates that Latinx residents would call to report dry wells "four or five times before they would give any information because they were super suspicious of the county." Due to a fear of communicating with the government and receiving their aid, residents would instead rely on informal water relationships with neighbors or approach a local non-profit they trusted. 
Historically, water stress and well failure was a common occurrence in the community. As one resident told us, "a lot of them hadn't had water [annually] for three or four months out of the year" (Frieda, White, East Porterville Resident, 8/15/18). Before and during the drought, a lack of water was a viewed as a relatively short term stressor compared to that of social and political disenfranchisement. Individuals could supplement household water through neighborly assistance or purchases at the store, but the perceived threats from government interaction, that of eviction, child removal, or deportation, represent potentially irreparable harm. Under normal circumstances, a household with dry well may not have received much assistance. However, during the drought, not reporting dry wells and avoiding government contact could prevent residents from connecting to the city water supply for a permanent, consistent source of water.

Ahmed (2004) describes fear as relating to perception of a potential future event that could have negative outcomes. She argues that fear becomes linked to objects, people, and collectives based on their association with the event in question. In this case, threats including potential deportation and child removal created fear despite the assurance residents received from officials that this was not the case. Since the government implicitly threatens the livelihoods of Latinx residents, fear is then associated with both government entities and the water services they provide. This affects both short-term and long-term mechanisms of water access in ways that did not affect white residents. In the short-term, residents did not want to report their addresses when retrieving water from distribution centers and were unable to request temporary water tanks for their homes.

In the long-term, residents' inability to report their water shortage meant the government did not connect their homes during the water system consolidation project that completed in 2018. 345 homes continued to rely on inconsistent wells or other sources of water and, for some of them, fear was a deciding factor for this choice. This example shows that fear, produced in the context of political disenfranchisement, water shortage, and government interaction, acts as an immaterial barrier to the flow of water. Fear inhibited access to free bottles and tanks of water, delayed piping of water through to the community, and prevented households from receiving access to city water. Due to the delay in assistance, fear even worsens and prolongs the experiences of suffering. Suffering and fear also come in conflict with one another. Residents wanted to stop suffering during the drought, but this would require getting water, which is attached to fear of government interaction. Residents had to grapple with the desire for safety motivated by fear and the desire to ease the pain associated with suffering. As a result, a cycle forms between hydro-social structures informing emotions that, in turn, affect the flow of water and other emotional experiences.

\section{Embarrassment and helplessness}

Cultural norms around water security created a sense of embarrassment for residents whose wells went dry. East Porterville residents are a "fiercely independent people" (Dennis Townsend, White, County Supervisor-Elect 8/16/18) who rarely ask the government for help. People expect to take care of themselves and for the government to stay out of their lives. When they lost water, government presence became a necessity and constant in their lives, this led to feeling of immense embarrassment and subjection to a mild form of governmentality. During the water crisis, many people went without water for the first time in their lives. Students were bullied by their peers for not showering, and adults refused to tell their neighbors of their loss. A quote from Marcos (8/9/18), a Latino high school student at the time of the crisis, exemplifies what this felt like:

You think in your mind like oh, we have so much water it's not gonna run out. You think about the ocean, we have lakes nearby, we have rivers nearby, never once in your head does it occur to you [that] you're gonna lose your water and then when the drought first struck it was kinda embarrassing. 
To community members like Marcos, water access was normalized. Losing water, and then asking to access it in another's home created a sense of embarrassment. While he was able to shower through alternative sources, this perpetuated a feeling of helplessness:

I remember it was kinda weird going to school and showering over there, having to ask my friends, 'hey can I shower at your place?' It was just this feeling of helplessness because there wasn't anything you could physically do about it no matter how hard you tried.

This combined feeling of helplessness and shame created an additional hurdle to access water resources and seek help from others. As Munt (2007) describes, the body is often a site of shame, but it is particularly exposed when transgressing social norms, where shame is more likely to restrict an individual's agency or make them vulnerable to criticism. In the United States, household water access is normalized, so using public showers exposed residents' lack of household water. This exposure led to a sense of embarrassment, restricting people's desire, and therefore ability, to use the showers. Over time, as public showers became normalized within the community, they became easier to access from an emotional standpoint.

For others, embarrassment created a barrier to obtaining drinking water. For example, Frieda's well went dry early in the drought, putting her, her family, and her animals at risk. She felt "stupid" for feeling embarrassed and not telling anyone about her water situation, even though her neighbor quickly helped her once he found out. Once Frieda learned about the community-wide water shortage, she began to distribute bottled water that she purchased or that was donated to her. However, she often missed households if she was unaware of their need. Frieda speaks to her own embarrassment and how it presented itself in the community while she was passing out water. She was stopped by a young girl after she passed her house without dropping off water:

I had gone there before and they had water, they had gotten a well fixed. Well they were out of water [again], and I said well why didn't you tell me? She says my mother was too ashamed. Same way I felt, isn't it funny? She didn't want to tell anybody we were out of water. I guess you feel like you're not doing something right... [not] taking care of your family, taking care of your home. (Frieda, White, East Porterville Resident, 15 Aug. 2018)

Shame is often associated with blaming oneself for a particular shortcoming (Gilbert and Miles 2000) as evidenced in Frieda's remark that "you feel like you're not doing something right." Shame such as this causes one to feel excluded from others, alone and unable to ask for help (Sobral 2019).

There were also gendered dynamics of shame and embarrassment. As mentioned above, women often associated suffering with the inability to perform household chores and taking care of the family through specific duties, while men often associated suffering with a sense of personal failure. These dynamics arise again here. Women felt ashamed that they were unable to perform their daily chores, at times leaving the family without clean dishes, fresh meals, or laundered clothing. In contrast, men felt embarrassed because, in their eyes, they failed to provide the resource itself, rather than the activities associated with it, to the family. Often, they would try to reestablish the flow of water on their own through an exchange of goods or, as discussed above, digging a new well in order to maintain a sense of pride and forgo embarrassment.

Embarrassment engages with hydro-social structures in similar ways to fear. It restricts residents' ability to benefit from alternative sources of water access; thus, serving as a barrier to accessing the water provided at no cost by non-profits, neighbors, or government officials. Embarrassment is primarily a reflection of culture in East Porterville and the U.S. more broadly. As we have noted, in East Porterville there is a strong sense of individualism and the belief that one should be able to take of oneself. However, this became extremely stressed during the water shortage.

Water shortages happen throughout America, but water is often considered a 'given' within most communities. This makes the lack of water abnormal and it is held up to immense media scrutiny. Normalized 
water access across the U.S. magnified the stigma of water shortage for East Porterville residents, making them feel further outside cultural norms. Furthermore, there are cultural expectations surrounding water and gender. Men expect to be resource providers, making the water available for the household by either providing the primary source of income or physically making water flow, while women expect to use the water for household chores like dishwashing and laundry. The embarrassment barrier has obvious economic consequences by requiring additional time and money for water retrieval. Embarrassment, like fear, also reinforces stress and suffering among residents because they do not know where their next water source will come from, who will provide it, nor how to ask for it. Suffering also pushes people to overcome their embarrassment because water is a necessary resource for life and normalcy. Emotions conflict with and build upon one another because of the need for water, physical safety, and mental wellbeing.

\section{Emotional appeals for water access}

Compassion and frustration associated with the lack of water motivated action to increase water access in the community. The emotional experiences described above may contribute to limited water access, but they were also shared with others inside and outside of the community. Individuals drew on these emotions to make appeals that affected the subjectivities of others and altered the distribution of water.

\section{Compassion among community actors}

Compassion increased opportunities for some individuals to access water but not everyone benefited due to personal emotional barriers discussed earlier such as shame, fear, and embarrassment. Recognizing the suffering experienced by members of the community, many individuals showed compassion, or a desire to relieve suffering. In this case, compassion is conceptualized as a deeper and more motivating sense of sympathy, where a person does not only understand the suffering of someone else, but actively tries to relieve them of stress. The most direct compassionate responses, especially early during the drought period, came from neighbors:

[Our neighbor] says 'just hook up to [my well].' So, we had a hose going across the road over here. But then his landlord said 'if that pump wears out, you're gonna have to pay for it, so don't do it.' He felt so bad about it. He says [that his landlord] goes home at five o'clock, we'll hook up after... Take it down the next day. (Ralph, White, County Resident, 7/25/18)

In this instance, the neighbor risked his own wellbeing for Ralph's family. First, the neighbor was putting additional stress on both his well and pump. By pumping water for Ralph, the neighbor was at greater risk of losing water himself. Furthermore, he risked retribution from his landlord; he could have been evicted from his home or held financially responsible for his actions. Despite this, he felt compelled to help because of Ralph's need. Similar actions happened across East Porterville, where you would see "hoses across streets" and "water angels" delivering bottled water to their neighbors. Such informal community efforts provided immediate water access opportunities for those without water. However, this assistance was not uniform across the community. Although there was significant assistance between those living in the area, landlords were not as quick to provide aid. Oftentimes, these landlords were white, lived outside of the community, and exploited their tenants by providing substandard housing. During the drought, residents were afraid to report their landlords for fear of being evicted or reported to immigration enforcement. It is uncertain whether landlords felt greed, anger, distaste, or an otherwise malicious attitude toward their tenants. Regardless, tenants reported feeling discriminated against, fearful, and exploited by their landlords, in sharp contrast to the help provided by many individuals in and around the community.

Beyond neighborly assistance, the suffering of residents played a key role in local non-profit response. Maria ran a non-profit organization with assistance from volunteers including her husband, Felipe. Both were important members of the government task force, but were inspired to help beyond this role: 
Felipe: [M]eetings went on for several months with no solution. We got tired of going to the meetings because nobody was coming up with a solution to this issue. So what [our organization] did, because there was nothing happening, we started water drives. Then it started getting out to reporters and newspapers and everything. Then we started doing water drives and started handing out water to people. We created a little water system... [using] donations [of] what they call three hundred-gallon totes...

Maria: [Shows a photo] This is Claudia. Claudia has breast and bone cancer. She was our first family that we went to where we had the three hundred-gallon totes and then just a bucket to take in the house to flush her toilets.

Felipe: Initially, the object was to try to get them water to flush their toilets and stuff. (Latinx, Local Experts, 7/25/18)

Maria and Felipe worked in the community daily, confronting its suffering firsthand. Further motivated by frustration with the government, they began to provide water access opportunities to the community to relieve suffering as quickly as possible, if only in the short-term. The compassion exhibited by Latinx community leaders was most readily received by Latinx residents of East Porterville. Although Latinx and white local experts, residents, and officials attempted to help the community, Latinx residents felt the least fear approaching programs and individuals directly associated with Latinx-led organizations or individuals who their friends could vouch for. Over time, efforts made by white individuals were better received after they had established themselves as trustworthy and helpful.

Despite the negative effects of fear, embarrassment, and suffering, the visibility of these emotions appealed to the compassion and frustration of others. This was an implicit appeal; impacted households did not intentionally mobilize or display their suffering to receive compassionate support. Rather, suffering was relationally shared among the community, inspiring others to act and relieve their strife. Eventually, the water system consolidation benefitted a large section of the community, even helping those that were unable to share their emotions with others or did not receive assistance from their landlord. There is an apparent paradoxical effect of emotions wherein water access may be limited by emotional barriers, but these exact barriers may motivate actions that increase water access opportunities.

\section{Sympathy, duty, and shaming among government actors}

Residents and local experts were frustrated by the slow government response to the water crisis, encouraging them to make direct emotional appeals to city, county, and state officials. One resident described her attempts to "get on the news and shame [them]" for the lack of action. Local experts acted as "a thorn" in the side of government actors. International media outlets published various accounts of the frustration and suffering among residents. These actions likely pressured government officials to act quickly and effectively to fix the problem. Munt (2007) argues that shame, while possibly restricting, is at times necessary for initiating change. In contrast to the shame that prevented water access, residents shamed government officials into action, leading to the creation of new water access opportunities. Outside of outward attempts to shame officials, other residents and local experts visited the state capital and participated in the government task force. Through these venues, they expressed their suffering directly to decision makers, appealing to senses of sympathy for the struggle of living without water and appealing to officials' duty to the constituents they serve. In contrast to implicit appeals to compassion, these actions were explicit appeals to evoke action from government actors by mobilizing their own emotions and eliciting emotional response.

The effects of these appeals were expressed by officials at various levels. Some officials, like City of Porterville councilmember Virginia Gurrola, began to search for solutions immediately. Virginia was one of a few officials on the ground in the community, gathering information and visiting households because she was sympathetic to their cause. Once she recognized the hardship among East Porterville residents, she considered the crisis "a humanitarian issue" affecting the city's "neighbors" (Latina, 7/26/18). Despite a lack of jurisdiction or legal obligation to East Porterville, she quickly encouraged the formation of a city task force to respond to 
the water shortage. The City of Porterville began to evaluate potential pathways to water security, facilitating the eventual construction of the water system consolidation project with state assistance.

State Assemblyman Devon Mathis "lost sleep over this thing for years" while trying to find a solution that worked for all sides involved, expressing his sympathy for residents, but also his duty to both the government and constituents. During the drought, officials recognized fear as an emotional barrier to water access. Normally, immigration may be on their political agenda, but in this instance, they claimed a sympathetic approach:

We didn't want people to shy away, because a lot of people were originally shying away - not getting the help they needed because they were afraid of going to a government agency, thinking they're gonna get in trouble for some other violation. For me, my number one was making sure, you get the water you need water. Water's the element of life. Like, dude, you need water. (Devon Mathis, White, State Assemblyman, 8/10/18)

As Devon states, the goal was to provide water to everybody. However, this outwardly sympathetic approach could simply be a strategy to 'save face.' If government officials had not provided water, the government would have been subjected to intense media scrutiny. Conveniently, invoking a sense of duty and sympathy makes the officials appear in a better light. Thus, government officials may express positive emotions to increase their likeability, decrease their personal shame, and reduce negative attachments to their policies.

Not all residents felt capable of visiting government offices, however. Many Latinx residents were fearful of visiting city hall to express their needs because of immigration and housing concerns. Other residents were embarrassed by their little-to-no English and worried about their ability to express themselves, despite the presence of interpreters. For these residents, they were most likely to appeal to local non-profits run by members of the Latinx community where they felt safe and heard.

Regardless of the specific emotional influence on officials and their elicited effect, emotions within the community helped to push for change and government action. In one instance, the county sent out "uniformed off-duty firefighters" to collect information in East Porterville but quickly recognized that fear prevented communication with the public. This realization led to a change in strategy that involved coordinating with Latinx volunteers and community members to gain access to the community, to learn about the problems present, and to build trust. Through the understanding of and political impetus to relieve suffering in the community, the government coordinated improved efforts to provide water access opportunities. The solution put forward by the government even engaged many of the landlords that were not compelled by the suffering of their tenants. Connecting a home to the city water supply through the water project represented about ten thousand dollars of government funded improvements to residential properties. Many landlords took advantage of this opportunity because of the value added to their property, and not because of emotional appeals by residents.

Between compassion, the shaming of others, and sympathy, we see a further development of the cyclical nature of hydro-social structures and emotions. Politics, culture, and hydrology collided during the water shortage, creating an array of emotions among residents. These emotions would define the experience of the drought; be withheld from and shared with each other; and would help and prevent water access in the short and long term. Throughout the drought period, emotions were formed relationally amongst all actors by socionatural assemblages, while simultaneously producing new hydro-social flows of power and water. Experiences, and emotions, will create new experiences with water into the future.

\section{Conclusions}

Emotion is deeply embedded in water relations in the historically marginalized Latinx community of East Porterville, California. This study showed that emotions are an embodied site of water struggles (see also Sultana, 2009; 2011), integrated into the complexities of the hydro-social cycle. Hydro-social structures, including the political disenfranchisement of the Latinx community, cultural norms surrounding water access 
and use, and the material availability of water, worked to produce various emotional experiences in residents and individuals outside of the community. In East Porterville, individuals linked water and its absence to various emotions (such as embarrassment, fear, shame, and compassion), which served as barriers and gateways to water access. East Porterville residents suffered from the lack of water in their homes, worsening their already marginalized position in society. Due to social norms, immigration status, and political disenfranchisement, a lack of water access produced the emotional barriers of shame and fear. Rather than being exposed to the psychological, material, and social risks associated with these emotions, residents continued to suffer without consistent water in their homes. On the other hand, suffering among residents inspired compassion, shame, and duty in others, opening new opportunities for personal and community access to public water.

These findings support other work that shows emotion motivates community action and resource struggles (González-Hidalgo and Zografos 2017; Moore 2005; Morales and Harris 2014; Sultana 2011, 2015; Wright 2012) and that individuals exert power by claiming access to resources based on their suffering (Moore 2005; Sultana 2011). Through these acts, they not only change political relationships but also change the physical flow of water [?] and the philosophical underpinnings of water locally (Jepson et al. 2017). As a result, emotions are agents of change within the hydro-social cycle, both positively and negatively impacting water access for individuals. This is not to overstate that emotions are the only means for individuals to influence the hydro-social flows, or that state actors only act according to others' or their own emotional experiences. Other factors, including, but not limited to, policies, governance structures, technologies, agriculture, groundwater basins, and climate remain part of the larger picture. In this study we show the roles of individual actors and their embodied experiences in the hydro-social cycle, where emotions influenced more-than-rational decision making that altered hydro-social relationships. We argue that individual water access within the household is not simply determined by structural processes but is influenced by their personal agency and embodied experiences. The latter can (re)produce and contest the distribution of water and power in society.

To adequately address household water insecurity, there must be a recognition of emotional barriers to water access, the embodied trauma of water loss, and the dramatic impacts that it has for marginalized groups. Local institutions can tackle this challenge by working with communities to foster trust, build social cohesion, and mutual support. They can further serve as a bridge between residents and government institutions to overcome emotional barriers to water insecurity. In East Porterville, residents felt comfortable reporting their water problems to other community members and non-profit leaders who worked outside of the government, were of a similar racial/ethnic background, and could be trusted based on previous work in the area. These same relationships encouraged residents to participate in the water project. However, there remain winners and losers in East Porterville, where emotional barriers have contributed to the reproduction of marginalized status, as seen in the case of some undocumented immigrants. Although local actors tried to address these issues by building trust in the community, it was too little too late. Broader socio-political forces created insurmountable personal barriers. To have equitable benefits from water access opportunities, there must be a culture of trust between members of society, where individuals feel safe, heard, and cared for. This requires a transformative shift in state and national politics, and through consistent, local trust-building efforts that attend to historic structures of marginalization and social injustices.

\section{References}

Acharya, A. 2015. The cultural politics of waterscapes. In Bryant, R. (ed). The international handbook of political ecology. Cheltenham: Edward Elgar. Pp. 373-386.

Ahmed, S. 2004. Affective economies. Social Text 22(2): 117-139.

Anderson, M.W. 2007. Cities inside out: race, poverty, and exclusion at the urban fringe. UCLA Law Review 55: 1095.

Bakker, K. 2002. From state to market? Water mercantilización in Spain. Environment and Planning A: Economy and Space 34(5): 767-790.

Bakker, K. 2012a. Water: political, biopolitical, material. Social Studies of Science 42(4): 616-623.

Bakker, K. 2012b. Water security: research challenges and opportunities. Science 337(6097): 914-915. 
Balazs, C.L., R. Morello-Frosch, A.E. Hubbard, and I. Ray. 2011. Social disparities in nitrate-contaminated drinking water in California's San Joaquin Valley. Environmental Health Perspectives 119(9): 1272.

Balazs, C.L., R. Morello-Frosch, A.E. Hubbard, and I. Ray. 2012. Environmental justice implications of arsenic contamination in California's San Joaquin Valley: a cross-sectional, cluster-design examining exposure and compliance in community drinking water systems. Environmental Health 11(1): 84.

Boelens, R. 2014. Cultural politics and the hydrosocial cycle: water, power and identity in the Andean highlands. Geoforum 57: 234-247.

Bondi, L. 2005. Making connections and thinking through emotions: between geography and psychotherapy. Transactions of the Institute of British Geographers 30(4): 433-448.

Bondi, L. 2007. The place of emotions in research: from partitioning emotion and reason to the emotional dynamics of research relationships. In Davidson, J., M. Smith, and L. Bondi (eds.). Emotional geographies. Burlington: Ashgate. Pp. 231-246.

Cantor, A. 2017. Material, political, and biopolitical dimensions of "waste" in California water law. Antipode 49(5): 1204-1222.

Cleaver, F. and K. Hamada. 2010. 'Good' water governance and gender equity: a troubled relationship. Gender \& Development 18(1): 27-41.

Coe, A.B. and A. Schnabel. 2011. Emotions matter after all: how reproductive rights advocates orchestrate emotions to influence policies in Peru. Sociological Perspectives 54(4): 665-688.

Cohen, D.T., G.W. Hatchard, and S. G. Wilson. 2015. Population trends in incorporated places: 2000 to 2013. U.S. Department of Commerce, Economics and Statistics Bureau, U.S. Census Bureau: 19.

Collins, T.W. 2010. Marginalization, facilitation, and the production of unequal risk: the 2006 Paso del Norte floods. Antipode 42(2): 258-288.

Cousins, J.J. and J.P. Newell. 2015. A political-industrial ecology of water supply infrastructure for Los Angeles. Geoforum 58: 38-50.

Creswell, J.W. and D.L. Miller. 2000. Determining validity in qualitative inquiry. Theory into Practice 39(3): 124-130.

Crow, B. and F. Sultana. 2002. Gender, class, and access to water: three cases in a poor and crowded delta. Society \& Natural Resources 15(8): 709-724.

Dallman, S., M. Ngo, P. Laris, and D. Thien. 2013. Political ecology of emotion and sacred space: the Winnemem Wintu struggles with California water policy. Emotion, Space and Society 6: 33-43.

Davidson, J. and C. Milligan. 2004. Embodying emotion sensing space: introducing emotional geographies. Social \& Cultural Geography 5(4): 523-532.

Department of Water Resources. 2018. East Porterville water supply project connects 755 homes. California Department of Water Resources.

DiCicco-Bloom, B. and B.F. Crabtree. 2006. The qualitative research interview. Medical Education 40(4): 314-321.

Doshi, S. 2017. Embodied urban political ecology: five propositions. Area 49(1): 125-128.

Elmhirst, R. 2011. Introducing new feminist political ecologies. Geoforum 42(2): 129-132.

Emerson, R.M., R.I. Fretz and L.L. Shaw. 2011. Writing ethnographic fieldnotes. Chicago: University of Chicago Press.

Faunt, C.C., M. Sneed, J. Traum and J.T. Brandt. 2016. Water availability and land subsidence in the Central Valley, California, USA. Hydrogeology Journal 24: 675-684.

Fears, D. 2016. No running water and no solutions as California's driest county despairs. The Washington Post, February 13, 2016.

Ford, A. 2020. Emotional landscapes of risk: emotion and culture in American self-sufficiency movements. Qualitative Sociology 2020.

Ford, B.Q. and L.B. Mauss. 2015. Culture and emotion regulation. Current Opinion in Psychology 3: 1-5. 
Gilbert, P. and J.N.V. Miles. 2000. Sensitivity to social put-down: its relationship to perceptions of social rank, shame, social anxiety, depression, anger and self-other blame. Personality and Individual Differences 29(4): 757-774.

Goldin, J.A. 2010. Water policy in South Africa: trust and knowledge as obstacles to reform. Review of Radical Political Economics 42(2): 195-212.

González-Hidalgo, M. and C. Zografos. 2017. How sovereignty claims and "negative" emotions influence the process of subject-making: evidence from a case of conflict over tree plantations from Southern Chile. Geoforum 78: 61-73.

González-Hidalgo, M. and C. Zografos. 2019. Emotions, power, and environmental conflict: expanding the 'emotional turn' in political ecology. Progress in Human Geography 44(2): 235-255.

Harris, L.M. 2006. Irrigation, gender, and social geographies of the changing waterscapes of southeastern Anatolia. Environment and Planning D: Society and Space 24(2): 187-213.

Hawkins, R., and J. Seager. 2010. Gender and water in Mongolia. The Professional Geographer 62(1): 16-31.

Hayes-Conroy, J. and A. Hayes-Conroy. 2010. Visceral geographies: mattering, relating, and defying. Geography Compass 4(9): 1273-1283.

Hayes-Conroy, J. and A. Hayes-Conroy. 2013. Veggies and visceralities: a political ecology of food and feeling. Emotion, Space and Society 6: 81-90.

Hohenthal, J., M. Räsänen, and P. Minoia. 2018. Political ecology of asymmetric ecological knowledges: diverging views on the eucalyptus-water nexus in the Taita Hills, Kenya. Journal of Political Ecology 25(1): 1-19.

Jepson, W. and H.L. Brown. 2014. 'If no gasoline, no water': privatizing drinking water quality in south Texas colonias. Environment and Planning A: Economy and Space 46(5): 1032-1048.

Jepson, W., J. Budds, L. Eichelberger, L.M. Harris, E. Norman, K. O'Reilly, A. Pearson, S. Shah, J. Shinn, and C. Staddon. 2017. Advancing human capabilities for water security: a relational approach. Water Security 1: 46-52.

Jepson, W. and E. Vandewalle. 2016. Household water insecurity in the global north: a study of rural and periurban settlements on the Texas-Mexico border. The Professional Geographer 68(1): 66-81.

Jewitt, S. and H. Ryley. 2014. It's a girl thing: menstruation, school attendance, spatial mobility and wider gender inequalities in Kenya. Geoforum 56: 137-147.

Lawson, V., L. Jarosz, and A. Bonds. 2010. Articulations of place, poverty, and race: dumping grounds and unseen grounds in the rural American Northwest. Annals of the Association of American Geographers 100(3): 655-677.

Linton, J., and J. Budds. 2014. The hydrosocial cycle: defining and mobilizing a relational-dialectical approach to water. Geoforum 57: 170-180.

Loftus, A. 2009. Rethinking political ecologies of water. Third World Quarterly 30(5): 953-968.

London, J., A. Fencl, S. Watterson, J. Jarin, A. Aranda, A. King, C. Pannu, P. Seaton, L. Firestone, M. Dawson and P. Nguyen. 2018. The struggle for water justice in California's San Joaquin Valley: a focus on disadvantaged unincorporated communities. Davis: UC Davis Center for Regional Change.

Lund, J., J. Medellin-Azuara, J. Durand and K. Stone 2018. Lessons from California's 2012-2016 drought. Journal of Water Resource Planning and Management 144(10): 04018067.

Main, A., E.A. Walle, C. Kho and J. Halpern 2017. The interpersonal functions of empathy: a relational perspective. Emotion Review 9(4): 358-366.

Moore, D.S. 2005. Suffering for territory: race, place, and power in Zimbabwe. Durham: Duke University Press.

Morales, M.C. and L.M. Harris. 2014. Using subjectivity and emotion to reconsider participatory natural resource management. World Development 64: 703-712.

Munt, S.R. 2007. Queer attachments: the cultural politics of shame. Abingdon: Routledge. 
Ngai, M.M. 2014. Impossible subjects: illegal aliens and the making of modern America. Princeton: Princeton University Press.

Nightingale, A.J. 2011a. Beyond design principles: subjectivity, emotion, and the (ir)rational commons. Society \& Natural Resources 24(2): 119-132.

Nightingale, A.J. 2011b. Bounding difference: Intersectionality and the material production of gender, caste, class and environment in Nepal. Geoforum 42 (2): 153-162.

Nightingale, A.J. 2013. Fishing for nature: the politics of subjectivity and emotion in Scottish inshore fisheries management. Environment and Planning A 45(10): 2362-2378.

Octavianti, T. and K. Charles. 2019. De- and re-politicisation of water security as examined through the lens of the hydrosocial cycle: the case of Jakarta's sea wall plan. Water Alternatives 12(3): 1017-1037.

de Onís, C. M. 2017. What's in an 'x'? An exchange about the politics of 'Latinx.' Chiricú Journal: Latina/o Literatures, Arts, and Cultures 1(2): 78-91.

O'Reilly, K. 2006. "Traditional" women, "modern" water: linking gender and commodification in Rajasthan, India. Geoforum 37: 958-972.

Orlove, B. and S.C. Caton. 2010. Water sustainability: anthropological approaches and prospects. Annual Review of Anthropology 39(1): 401-415.

Pauli, B.J. 2019. Flint fights back: environmental justice and democracy in the Flint water crisis. Cambridge: MIT Press.

Perramond, E.P. 2016. Adjudicating hydrosocial territory in New Mexico. Water International 41(1): 173-188.

Perrone, D. and S. Jasechko. 2017. Dry groundwater wells in the western United States. Environmental Research Letters 12(10): 104002.

Pile, S. 2010. Emotions and affect in recent human geography. Transactions of the Institute of British Geographers 35(1): 5-20.

Pulido, L. 2016. Flint, environmental racism, and racial capitalism. Capitalism Nature Socialism 27(3): 1-16.

Radonic, L. 2019. Becoming with rainwater: a study of hydrosocial relations and subjectivity in a desert city. Economic Anthropology 6(2): 291-303.

Ranganathan, M. and C. Balazs. 2015. Water marginalization at the urban fringe: environmental justice and urban political ecology across the north-south divide. Urban Geography 36(3): 403-423.

Reisner, M. 1993. Cadillac desert: the American West and its disappearing water. London: Penguin.

Rose, G. 1997. Situating knowledges: positionality, reflexivities and other tactics. Progress in Human Geography 21(3): 305-320.

Schoenberger, L. and A. Beban. 2018. "They turn us into criminals": embodiments of fear in Cambodian land grabbing. Annals of the American Association of Geographers 108(5): 1338-1353.

Sharp, J. 2009. Geography and gender: what belongs to feminist geography? Emotion, power and change. Progress in Human Geography 33(1): 74-80.

Singh, N.M. 2013. The affective labor of growing forests and the becoming of environmental subjects: rethinking environmentality in Odisha, India. Geoforum 47: 189-198.

Singh, N.M. 2018. Introduction: affective ecologies and conservation. Conservation and Society 16(1): 1.

Sobral, A. 2019. 'My body is burning with the shame of not belonging': gender, violence and shame in diasporic Somali women's writings. European Journal of English Studies 23(3): 326-339.

Strang, V. 2005. Common senses: water, sensory experience and the generation of meaning. Journal of Material Culture 10(1): 92-120.

Street, A., C. Zepeda-Millán, and M. Jones-Correa. 2015. Mass deportations and the future of Latino partisanship. Social Science Quarterly 96(2): 540-552.

Street, R.S. 2004. Beasts of the field: a narrative history of California farmworkers, 1769-1913. Stanford: Stanford University Press. 
Sugg, Z. 2018. An equity autopsy: exploring the role of water rights in water allocations and impacts for the Central Valley Project during the 2012-2016 California drought. Resources 7(1): 12.

Sultana, F. 2009. Fluid lives: subjectivities, gender and water in rural Bangladesh. Gender, Place and Culture 16 (4): 427-444.

Sultana, F. 2011. Suffering for water, suffering from water: emotional geographies of resource access, control and conflict. Geoforum 42(2): 163-172.

Sultana, F. 2015. Emotional political ecology. In Bryant, R. (ed). The international handbook of political ecology. Cheltenham: Edward Elgar. Pp. 373-386.

Swyngedouw, E. 1999. Modernity and hybridity: nature, regeneracionismo, and the production of the Spanish waterscape, 1890-1930. Annals of the Association of American Geographers 89(3): 443-465.

Swyngedouw, E. 2009. The political economy and political ecology of the hydro-social cycle. Journal of Contemporary Water Research \& Education 14(1): 56-60.

Thomas, D.R. 2006. A general inductive approach for analyzing qualitative evaluation data. American Journal of Evaluation 27(2): 237-246.

Truelove, Y. 2011. (Re-) conceptualizing water inequality in Delhi, India through a feminist political ecology framework. Geoforum 42(2):143-152.

Truelove, Y. 2019. Gray zones: the everyday practices and governance of water beyond the network. Annals of the American Association of Geographers 109(6): 1758-1774.

Walker, R. 2004. The conquest of bread: 150 years of California agribusiness. New York: The New Press.

Walsh, C. 2018. Virtuous waters: mineral springs, bathing, and infrastructure in Mexico. Oakland: University of California Press.

Wilson, N.J. 2014. Indigenous water governance: insights from the hydrosocial relations of the Koyukon Athabascan village of Ruby, Alaska. Geoforum 57: 1-11.

Worster, D. 1982. Hydraulic society in California: an ecological interpretation. Agricultural History 56(3): 503-515.

Wright, S. 2012. Emotional geographies of development. Third World Quarterly 33(6): 1113-1127.

Wutich, A. 2009. Intrahousehold disparities in women and men's experiences of water insecurity and emotional distress in urban Bolivia. Medical Anthropology Quarterly 23(4): 436-454.

Wutich, A. 2011. The moral economy of water reexamined: reciprocity, water insecurity, and urban survival in Cochabamba, Bolivia. Journal of Anthropological Research 67(1): 5-26.

Wutich, A., J. Budds, L. Eichelberger, J. Geere, L.M. Harris, J.A. Horney, W. Jepson, E. Norman, K. O'Reilly, and A.L. Pearson. 2017. Advancing methods for research on household water insecurity: studying entitlements and capabilities, socio-cultural dynamics, and political processes, institutions and governance. Water Security 2: 1-10.

Zhen, N., J. Barnett, and M. Webber. 2020. Is trust always a precondition for effective water resource management? Water Resources Management 34: 1423-1436. 